REVIEW ARTICLE

\title{
Do all nocturnal asthmatics need a polysomnographic evaluation?
}

\section{T. Mohankumar}

Institute of Pulmonary Medicine \& Research, Sri Ramakrishna Hospital, Coimbatore

Indian J Sleep Med 2009; 4.2, 43-44

W hen asthmatics are awake, they will or can turn to their inhalers to open their airways. But when they sleep, many of them continue to struggle with breathing and are helpless - their sleeprelated problems may help doctors better diagnose and treat their patients' asthma.

Repeated arousals during sleep are common in obstructive sleep apnea and in nocturnal asthma. This may also result in changes in oronasal airflow, decreases of saturation and respiratory effort changes. Frequently nocturnal asthmatics may mimic symptoms of OSA with daytime sleepiness (1-4).

A significant number of nocturnal asthmatics may have OSA also. This may be due to high incidence of both in the general population. Gastro-esophageal reflux disease (GERD) may also result in these people with may produce upper and lower airway inflammation (5).The negative airway pressure increases during apneic episodes to overcome upper airway obstruction may produce gastric reflux.(6)

Nasopharyngeal congestion may predispose to worsening of bronchoconstriction and OSA as a result of mouth breathing. Irritation of the upper airways produce periodic breathing and decreased upper airway obstruction during sleep in nocturnal asthmatics. Increased bronchial activity may be due to hypoxemia in these cases. Recurrent episodes of coughing, choking and breathlessness are common in both.

Treatment with methyl xanthines, beta agonists and systemic steroids lead to fragmented sleep like in OSA in

\author{
Address for correspondence \\ Dr T. Mohan Kumar \\ HOD \& Senior Consultant Pulmonologist, \\ Institute of Pulmonary Medicine \&Research, \\ Sri Ramakrishna Hospital, Coimbatore 641044, \\ email: tmkdr@hotmail.com
}

nocturnal asthmatics (7).

Nocturnal asthma and OSA have similar circadian patterns with changes in peak expiratory flow rates and forced expiratory volume in one second (FEV1) in early morning hours $(8,9)$ Exhaled nitric oxide is lower in the morning in asthmatics leading to more bronchoconstrition and increase in airway resistance $(10,11)$ Melatonin is high in asthmatics during night which may also increase symptoms at night due to proinflammatory effects (12). Number of eosinophils $(13,14)$ and levels of cortisol $(15$, 16) may contribute to airway inflammation in asthma during night. Because of these reasons, nocturnal asthma may be considered as some other form of sleep disordered breathing (SDB).

SDB symptoms like insomnia, excessive day time somnolence are common in asthma $(17,3-5) .55 \%$ of the asthmatics reported excessive somnolence and $47 \%$ had a score of more than 11 on the Epworth Sleepiness Scale (18, 19). $49 \%$ men and $33 \%$ women met criteria for OSA by the Sleep Apnea Scale of Sleep Disorders Questionnaire (SASDQ) (21) thus concluding beyond doubt that symptoms of SDB are common in asthmatics. High prevalence of snoring and correlation to SA-SDQ is common in asthmatics (21).

Continuous positive airway pressure therapy (CPAP) may be useful in the treatment of nocturnal asthma in apneic asthmatics $(22,23)$. The CPAP improves nocturnal and diurnal peak expiratory flow up to two weeks after beginning of therapy in those with OSA and nocturnal asthma. (24) In those with nocturnal asthma alone, the expiratory flow worsened and sleep quality was disrupted. The use of oxygen alone has been found to be useful in nocturnal asthma.

The above data illustrates the importance of polysomnographic studies in nocturnal asthmatics who have OSA.

Indian Journal of Sleep Medicine (IJSM), Vol. 4, No. 2, 2009 


\section{References}

1. Guilleminault $\mathbf{C}$, Stoohs $R$, Clerk A et al. A cause of excessive daytime sleepiness: the upper airway resistance syndrome. Chest 1993; 104:781-787

2. Bohadana AB, Hannhart B, Teculescu DB. Nocturnal worsening of asthma and sleep disordered breathing. Asthma 2002; 39:85-100.

3. Larsson LG, Lindberg A, Franklin KA, Lundback B, Symptoms related to obstructive sleep apnea are common in subjects with asthma, chronic bronchitis and rhinitis in a general population. Respir Med 2001; 95:423-429.

4. Sutherland ER. Nocturnal asthma: underlying mechanisms and treatment. Curr Allergy Asthma Rep 2005; 5:161-167.

5. Theodoropoulos DS, Pecoraro DL, Efstratiadis SE. The association of gastro esophageal reflux disease with asthma and chronic cough in the adult, Am J Respir Med 2002; $1: 133-146$.

6. Ing $\mathbf{A J}, \mathrm{Ngu} M C$, Breslin $\mathrm{AB}$, Obstructive sleep apnea and gastroesophageal reflux. Am J Med 2000;108:120S-125S

7. Novak M, Sharpio CM, Drug induced sleep disturbances. Focus on nonpsychotropic medications. Drug Saf 1997; 16:133-149.

8. Sutherland ER, Nocturnal asthma: underlying mechanisms and treatment. Curr Allergy Asthma Rep. 2005;5:161-167.

9. Enright $\mathbf{P L}, \mathbf{M c}$ Clelland RL, Buist $A S$, Lebowitz MD; Cardiovascular Health Study Research Group. Correlates of peak expiratory flow liability in elderly persons. Chest $2001 ; 120: 1861-1868$.

10. Berry $\mathbf{M}$, Hargadon B,Morgan A et al .Alveolar nitric oxide in adults with asthma:evidence of distal lung inflammatiom in refractory asthma. Eur Respir J 2005;25:986-991.

11. Prasad A, Langford B, Stradling JR, Ho LP. Exhaled nitric oxide as a screening tool for asthma in school children. Respir Med 2005 Epub ahead of print.

12. Sutherland ER, Ellison MC, Kraft M, Martin RJ. Elevated serum melatonin is associated with the nocturnal worsening of asthma. J Allergy Clin Immunol 2003;112:513-517.

Indian Journal of Sleep Medicine (IJSM), Vol. 4, No. 2, 2009
13. Panzer SE, Dodge IS, Kelly EA, Jarjour NN. Circardian variation of sputum inflammatory cells in mild asthma. J Allergy Clin Immunol 2003; 11 1:308-312.

14. Howarth P. Small airways inflammation and asthma. Int J Clin Pract. 1998; 96:15-22.

15. Landstra AM, Postma DS, Boezen HM, Van Alderen WM. Role of serum cortisol levels in children with asthma. Am J Respir Crit Care Med 2002;165:708-712.

16. Weiner P, Berar-Yanay N, Davidovich A, Magadle R. Nocturnal cortisol secretion in asthmatic patients after inhalation of fluticazone propionate. Chest 1999; 116:931 934 .

17. Teodorescu M, Consens FB, Bria WF et al. Screening for symptoms of sleep disordered breathing among asthmatics. Sleep 2005;28:164

18. Johns MW. Day time sleepiness, snoring and obstructive sleep apnea: The Epworth Sleepiness Scale. Chest 1993; 103:30-33.

19. Johns MW. A new method of measuring daytime sleepiness: the Epworth Sleepiness Scale. Sleep $1991 ; 14540-545$.

20. Weatherwax KJ, Lin X, Marzec ML, Malow BA. Obstructive sleep apnea scale of the sleep disorders questionnaire (SASDQ) is a useful screening instrument for obstructive sleep apnea in a disease specific population. Sleep Med $2003 ; 4: 517-521$.

21. Theodorescu M, Consens FB, Bria WF ET al.Correlates of excessive daytime sleepiness in asthmatics. Sleep. 2005; 28(suppl):297

22. Ciftici TU, CifticiB, GuvenSF, Kokturk O, Turktas H. Effect of nasal continuous positive airway pressure in uncontrolled nocturnal asthmatic patients with obstructive sleep apnea syndrome. Respir Med 2005;99:529-534.

23. Chan CS, Woodcock AJ, Sullivan CE. Nocturnal asthma: role of snoring and obstructive sleep apnea. Am. Rev Respir Dis. 1988; 137:1502-1504

24. Ciftici TU, Ciftici B, Guven SF et al, Effect of nasal continuos positive airway pressure in uncontrolled nocturnal asthmatic patients with obstructive sleep apnea syndrome. Respir. Med. 2005;99:529-534. 